\title{
Should this structure have been underpinned? - reflection after a quarter of a century.
}

Peter, Wynn, Anglia Polytechnic University, Department of Built Environment, Chelmsford, UK

\section{Keywords}

Insurers, loss_adjusters, surveyors, settlement, heave, monitoring, site_investigation

\begin{abstract}
A case study of a domestic structure that suffered damage as a result of foundation movement in the 1970s is examined. Conclusions and recommendations made at the time are re-visited in the light of limitations of the original site investigation and subsequent performance of the structure.
\end{abstract}

\section{Introduction}

The British insurance industry introduced cover for subsidence damage to domestic buildings on a general basis in 1971. Cover for heave was not included, but at the claim stage it is not easy to separate the two processes of damage. Reece (1977) reported that claims doubled each year to 1975 with possibly 3000 claims for heave and subsidence in that year (Crilly, 2001). Following two dry summers in 1975 and 1976, approximately 20000 claims for heave and subsidence were made in 1976 (Crilly, 2001). At the time these figures were a shock to the insurance industry, but are relatively small compared to the 40000 claims made annually in the late 1990s (Crilly, 2001). This paper examines the case of a pair of semi-detached houses that were the 
subject of a claim in 1976. It critically examines the investigations and the recommendations made and discusses, two and a half decades on, whether the ultimate decision not to underpin was well taken.

\section{Situation of the Properties}

The properties are situated in the CM postcode area and were constructed in 1967. The geological survey map of the area (Institute of Geological Sciences, 1975) shows the geology to consist of Head deposits overlying London Clay. The developers site plan (unpublished) site layout indicated that a ditch formerly passed through the site of the properties as shown in Figure 1 and that the bank to bed depth of this was about $2 \mathrm{~m}$. Examination of Ordnance Survey maps pre and post development shows that this ditch formed a field boundary with a wooded area to its left. Anecdotal evidence of older residents of the area indicates that the woodland was actually an orchard and that allotment gardens may have occupied the land to the right of the ditch.

\section{[Take in Figure 1]}

\section{Damage to the Properties}

Interior and exterior cracking was observed on Property A in early 1976 and exterior cracking only to Property B was observed in July 1977. All the cracks fell within the very slight to slight category of the BRE Classification (Tomlinson et al., 1978).

\section{Initial Site Investigation}

A Chartered Building Surveyor was appointed by the owners of Property A shortly after cracking to that property was first noticed and a loss adjuster was appointed by the 
insurers of that property. On instructions from the loss adjuster, a site investigation was carried out. This comprised a level survey, the sinking of 4 hand auger boreholes, excavation of 2 trial pits and associated laboratory testing.

\section{Level Survey}

Relative levels were taken at 14 locations around the exterior of the structure at the level of the damp proof membrane using the front corner of Property B as a datum. Indicative contours of the relative movement of the structure based on this levelling exercise are shown on Figure 2.

$$
\text { [take in Figure 2] }
$$

\section{$\underline{\text { Trial Pits }}$}

These showed the underside of the foundation to be $0.97 \mathrm{~m}$ below ground level in Trial Pit 1 and $0.71 \mathrm{~m}$ below ground level in Trial Pit 2. Both trial pits terminated in firm silty clay with the top of material identifiable as London Clay at a depth of $0.99 \mathrm{~m}$ below ground level in Trial Pit 2. A seepage of groundwater was encountered at the top of the footing in Trial Pit 1. Vane tests were conducted on the clay immediately below the footings

\section{$\underline{\text { Boreholes }}$}

These were sunk to a depth of $3 \mathrm{~m}$. All terminated in the brown weathered zone of the London Clay Formation. Above the London Clay a variable series of deposits was found including made ground, firm brown clay, a $0.4 \mathrm{~m}$ thick layer of grey organic clay in Borehole 2 and a $0.9 \mathrm{~m}$ thick layer of gravel in Borehole 3. Slight groundwater seepages were encountered in all of the boreholes.

\section{Laboratory Testing}


Moisture content determinations made on samples from Boreholes 1 and 3 showed that the material in Borehole 3 generally had a lower water content than the material from Borehole 1.

\section{Additional Site Investigation}

Borehole 5 was sunk on behalf of the owner of Property B in December 1976. Groundwater was encountered at a depth of a little over $1 \mathrm{~m}$ in Borehole 6 and rose to $0.7 \mathrm{~m}$ over a period of 90 minutes. A standpipe piezometer was installed in this borehole to allow subsequent monitoring of piezometric levels.

\section{Subsequent Monitoring}

\section{Piezometric Pressures}

The piezometer was dipped at generally fortnightly intervals from the time of installation until Spring 1979. Over this period the depth to the piezometric surface ranged from a minimum of $0.52 \mathrm{~m}$ (May 1978) to a maximum of $1.24 \mathrm{~m}$ (October 1978).

\section{Level Survey}

Further series of readings of relative levels around the damp course taken at monthly intervals between August 1977 and April 1978 showed individual changes of up to $10 \mathrm{~mm}$, although no clear pattern of relative movement could be determined.

In early 1978 the levelling points were replaced with monitoring related to a benchmark sleeved to a depth of $3 \mathrm{~m}$ below ground level at a location remote from the structure. Following this the maximum recorded movement over a period of 9 months was only $3 \mathrm{~mm}$. 


\section{Approach of NHBC and Loss Adjusters}

Both properties were covered by the NHBC 10 year 'guarantee' certificate at the time damage occurred. The NHBC Field Officer's report concluded in May 1978 that the defects had been caused by subsidence and that in the absence of underpinning the properties would continue to be subject to seasonal movement.

In August 1977 the Loss Adjuster for Property A advised that estimates for underpinnning should be obtained. However on receiving the NHBC report he commissioned a further engineer's report which, as a result of delay in its production, was able to take account of subsequent monitoring and suggested that a situation of relative stability had been achieved so that cosmetic repairs as an when required would be all that was necessary. The need for underpinning was opposed throughout by Loss Adjusters acting for the insurers of Property B.

\section{Subsequent History}

Cosmetic repairs, including some repointing of brickwork, were carried out to Property A in late 1979. No further cracking attributable to foundation movement has occurred to that property. It is understood that subsidence was not an issue when the property was subsequently sold in the early 2000 s. No repairs were made to the structure of Property B. Other than weathering, the crack in the brickwork of the front wall has not materially worsened and is still only of the order of $2 \mathrm{~mm}$ wide and does not extend beyond the base of the ground floor window or below the damp proof course (see Figure 3).

[take in Figure 3] 


\section{Discussion}

The investigation was probably typical of many carried out at the time but lacked a number of elements that would have increased the reliability of decisions based on it.

There was no investigation of the prior history of the site: the presence of the boundary ditch and the orchard mentioned earlier was not discovered as part of the investigation. Knowledge of this history may have indicated that at least part of the damage may have been the result of heave of the soil underlying the left part of the structure following tree removal, a largely one-off event.

The comments within the site investigation report concerning the lower water content of soils in Borehole 3 compared with Borehole 1 did not take account of the more granular nature of the latter.

The initial level survey used nails driven into the felt of the damp proof course as levelling points. There was therefore the risk that these points would move in a variable way under the weight of the staff, depending upon the extent to which temperature softened the felt at the time of the readings. The use of a corner of the structure as a benchmark only enabled relative movements to be ascertained during subsequent monitoring.

The initial NHBC report relied to a large extent on reported continued movement based on the use of the levelling survey. It is noteworthy that apparent movements were much reduced, indeed were within reading error, following the use of the independent benchmark and more robust levelling points, in spite of variations of the piezometric surface of up to $0.7 \mathrm{~m}$. This enabled the engineer appointed by the Loss Adjuster for 
Property A to take the view that movement had stabilised. It is speculated that in the absence of the new arrangements for the level surveys, a decision would have been taken to underpin the structure. It is clear from the subsequent history of the structure that this action would have been misguided.

\section{Conclusion}

It is apparent that the structure described had a near miss from unnecessary underpinning as the result of over-reliance on a deficient site investigation. The need for an appreciation of the importance of site history in "post mortem" investigations and the need to take account of the limitations of techniques used have not disappeared in the quarter of a century since the work described in this paper was carried out.

\section{References}

Crilly, M. (2001) "Analysis of a database of subsidence damage", Structural Survey Vol. 19 No. 1, pp. 7-14.

Institute of Geological Sciences, (1975) I: 50000 Chelmsford Sheet 241 Solid and Drift Edition, Ordnance Survey, Southampton.

Reece, B. (1977) "Insurance aspects of new work and remedial works", Course on House Foundations on Swelling / Shrinkable Clay, Polytechnic of Central London.

Tomlinson, M. J., Driscoll, R. and Burland, J. B. (1978) "Foundations for low-rise buildings", Structural Engineer Vol. 56A No. 6, pp 161-173. 